\title{
BYCIE I TRANSCENDENCJA - LÉVINAS I MARCEL
}

Współczesna filozofia przeżywa — przynajmniej w jednym ze swych nurtów — ostry kryzys dwóch kluczowych tematów filozofii klasycznej: Boga oraz bycia, a w szczególności ich wzajemnego związku. Bóg jako filozoficzny temat kontestowany jest z jednej strony przez coraz mniej żywotną myśl ateistyczną, w drugiej jednak także przez coraz bardziej żywotną myśl religijną: dla jednej strony Bóg nie osiąga nawet poziomu sensu wymaganego przez filozofię godną tego miana, dla drugiej — wyrasta ponad wszelką możliwą filozofię, niezdolną do dyskursu o Bogu, który by nie dokonywał immanentyzacji boskiej transendencji. Kryzys filozofii bycia zapowiadający się od dawna rozpoczął się na dobre - nieco paradoksalnie — od Sein und Zeit Heideggera. I właśnie od Heideggera idea bycia jawi się nie tylko jako równocześnie dwuznaczna i wtórna, ale także jako miejsce zdrady Boga. Bowiem w perspektywie bycia Bóg przekształca się nieuchronnie w najwyższy byt, który jest w istocie zakamuflowaną „wolą mocy" i przed którym nie można już ani się modlić, ani muzykować i tańczyć $^{1}$.

Tak więc nie tylko w ogóle „myślenie według bycia”, ale w szczególności myślenie Boga w perspektywie bycia wydaje się dla filozofii po Heideggerze niemożliwe - znamienny jest tutaj tytuł jednej z książek Jean-Luc Mariona: Dieu sans l'être (Paris 1982). Tytuł prowokujący: bo czy „Bóg bez bycia” j e s t, czy Go nie ma? I jak można uniknąć sensownie natarczywej banalności tego pytania? Marion ma jednak wielkiego poprzednika nie tylko w osobie Heideggera, ale przede wszystkim Emmanuela Lévinasa, z pewnością najgłębszego

*W tekście artykułu zastosowano skrótowe odnośniki do dzieł Lévinasa i Marcela (liczba oznacza stronę):

$\mathrm{AE}$ - E. Lévin as, Autrement qu'être ou au-delà de l'essence, Paris 1978.

EA - G. Marcel, Etre et avoir, Paris 1935.

EDE - E. Lévi in a s, En découvrant l'existence avec Husserl et Heidegger, Paris 1967.

EE - E. Lévin as, De l'existence à l'existant, Paris 1947.

JM - G. Marcel, Journal métaphysique, Paris 1927.

ME - G. Marcel, Le mystère de l'être, t. 2, Paris 1951.

PA - G. Ma rcel, Position et approches concrètes du mystère ontologique (dodatek do dramatu: Le monde cassé), Paris 1933.

PST - G. Marcel, Pour une sagesse tragique, Paris 1968.

RI - G. Marcel, Du refus à l'invocation, Paris 1940.

TA - E. Lé vin as, Le temps et l'autre, [w:] J. W ahl [...], Le choix, le monde, l'existence, Paris 1948. Taż praca Lévinasa została opublikowana oddzielnie w r. 1979 w Montpellier.

TI - E. Lé vi n as, Totalité et infini, Paris 1971.

${ }^{1}$ M. He id e g ge r, Identität und Differenz, Pfullingen 1957, s. 64. 
i najkonsekwentniejszego przedstawiciela „metafizyki pozaontologicznej”, metafizyki „ponad” i „poza” byciem. Chciałbym myśl Levinasa dotyczącą stosunku bycia i Transcendencji skonfrontować tu ze skromniejszą, ale ważną, i także na swój sposób nowatorską myślą Gabriela Marcela, dla którego Bóg w pobliżu człowieka - i bycie nie wykluczają się wzajemnie, ale właśnie znaczeniowo dopełniają i dlatego można, mimo wszystkich zastrzeżeń, powiedzieć: „Bóg jest”. Konfrontacja w łonie podobnej tradycji myślowej i przy pomimo przeciwieństw — wielu podobieństwach.

W pierwszej części spróbuję zarysować koncepcję bycia u Levinasa i Marcela; w drugiej postaram się ukazać u obu filozofów związek tych koncepcji $\mathrm{z}$ ideą boskiej Transcendencji; $w$ trzeciej wreszcie ukażę pewne założenia ich myśli, które same z siebie prowadzą do pewnych wniosków.

1. Jedynym zagadnieniem poruszającym myślenie Lévinasa jest zbudowanie filozofii Innego, tzn. uchwycenie znaczeń, kryjących się za spotkaniem $\mathrm{z}$ transcendencją drugiego człowieka, a przede wszystkim Boga. Spotkanie to jest możliwe w nie analizowanej w dotychczasowej filozofii sferze tego, co „ponad byciem". Czym jest dla Lévinasa bycie? Bycie jest nade wszystko anonimowością. Ujawnia się ona na dwa sposoby.

A. Możemy dokonać myślowo unicestwienia wszystkich rzeczy — eksperyment znany Arystotelesowi, Kantowi, Bergsonowi. Co pozostaje po tej destrukcji? Fakt nagiego ,że jest”. „Nieobecność wszystkich rzeczy powraca jako obecność [...] Jest po tej destrukcji rzeczy i bytów «pole sił» istnienia, pole bezosobowe [...] Fakt istnienia, który się narzuca, kiedy już nie ma niczego. I jest to anonimowe; nie ma nikogo i niczego co wzięłoby to istnienie na siebie" (TA 134 n.). Nie „,jest” to nic, co by „było”, a jednak właśnie ,jest”, to znaczy „istnieje” na sposób koszmaru: „bycie” znaczy tu „istnienie”. Koszmar ten Lévinas próbuje dookreślić poprzez fenomen bezsenności. W ciemności bezsennej nocy, w której znikają wszystkie byty, a wraz z nimi jakikolwiek uchwytny sens, pozostaje tylko horror ,absolutnie nieuchronnej obecności” (EE 94), skazanie nie na śmierć, lecz na jej niemożliwość, na niemożliwość nicości: „horror wykonuje skazanie na wieczną rzeczywistość, na bezwyjściowość istnienia” (EE 102). Bycie to piekło bycia, absurdalność, zło: „bycie jest złem” (TA 139). Ta Sartrowska lektura bycia wydaje się przede wszystkim rodem z Hegla: nicość zamienia się w bycie i na odwrót, ale triumfuje po Bergsonowsku bycie, które jest tu fałszywą nieskończonością koszmaru. Między tym byciem, a jakimkolwiek bytem panuje (na pozór) przepastna różnica — mówi Lévinas za Heideggerem.

B. Ale dialektyczna samokonstytucja bytu wychodząc $\mathrm{z}$ anonimowego 
istnienia wprowadza inny aspekt bycia, równie fundamentalny. „Aby mogło się pojawić to, co istnieje tym anonimowym istnieniem, trzeba by stało się możliwe wyjście z samego siebie i powrót do siebie, to znaczy samo tworzenie tożsamości. Przez swoją identyfikację to, co istnieje już się zamknęło w sobie: jest monadą i samotnością" (TA 140 n). W ten sposób wyłania się już jako korelat istnienia nie tylko to, co istnieje, lecz is t o ta. W jaki sposób?

Miejscem wyłaniania się bytu - który nazywa Lévinas hipostazą — jest a k t istnienia, który jest aktywnym wejściem w teraźniejszość — jeszcze ponad czasem - i w ten sposób zapanowanie nad istnieniem. Ale ten „pierwszy dzień wolności" jest równocześnie obciążeniem nieodwracalnością wyodrębnienia i samotności. Byt jako taki jest zamknięty w sobie, zmęczony własną haecceitas, zajęty sobą i - szuka zbawienia, chcąc jakoś ze siebie wyjść. Podstawową $\mathrm{z}$ tych prób jest najszerzej rozumiane poznawanie, a więc światło prawdy; przez nie ,podmiot oddziela się od siebie samego. Światło jest warunkiem takiej możliwości” (TA 156).

Otóż to oddzielanie się od siebie jest przede wszystkim Husserlowską konstytucją pierwotnej świadomości czasu, pierwotnym samopobudzaniem, wrażeniem. Aby jakakolwiek impresja mogła zostać zarejestrowana musi powstać minimalny dystans czasowy, a wraz z tym pierwotna intencjonalność, która od razu jest też pierwotną identyfikacją: impresja jest tylko jako właśnie przeszła, albo właśnie nadchodząca, inaczej mówiąc jako jedność retencji i protencji w łonie żywej, ale już czasowej teraźniejszości, w której „nic nie jest zgubione” (AE 41), gdyż każda retencja może być odnaleziona przez retencję retencji itd. a każda protencja może się przedłużać o nieskończone antycypacje. W ten sposób „czasowość, poprzez odstęp tożsamego w stosunku do siebie samego jest is t o tą i pierwotnym światłem, tym, które Platon odróżniał od widzialności tego, co widzialne i od przenikliwości oka” (AE 38). Gdyż ,istotą istoty”, by tak rzec, jest właśnie tożsamość w czasie, która umożliwia dopiero inteligibilność.

Ale identyfikacja istoty nie jest $\mathrm{z}$ kolei możliwa bez języka, który jest od razu dwuznacznością słowa-czasownika i nazwy-rzeczownika oraz ich wzajemnego złączenia. Czasownik „być”, który jest dla Lévinasa nie nazwą czasu, ale samym czasem, tzn. jego tożsamością w zmienności tężeje równocześnie w n a z w ę, która ustatycznia czasownik i zamienia w treść jako to, co mówione (le Dit) jako takie i zarazem to, o czym można mówić i o co pytać. W ten sposób powstaje temat i możliwość prawdy: „istota, to sam fakt, że jest temat, ukazywanie, doxa czy logos i przez to prawda" (AE 38). Gdy filozof pyta: co to jest bycie, pyta $\mathrm{z}$ konieczności o istotę, o prawdę istoty.

Otóż prawda jako to, co ukazane, jako temat jest nieodłączna z kolei od struktury i systemu, a więc Heglowskiej wiedzy absolutnej. Znaczenia wytryskują jedynie we wzajemnych relacjach: jedno jest przez drugie, drugie przez trzecie itd, tak iż razem dążą do utworzenia całości. Ale relacje są zawsze 
niepełne, system zawsze niekompletny, prawda zawsze w drodze i dlatego bycie zawsze skończone; dlatego podmiot myślenia czuje się powołany do tego, by wciąż na nowo ubogacać i synchronizować relacje, wciąż na nowo gromadzić w teraźniejszości to, co czas i niepamięć rozprasza. Co to oznacza? To, że podmiot przekształca się niepokojąco $\mathrm{w} \mathrm{n}$ a $\mathrm{r}$ zę $\mathrm{dz}$ z e bycia jako prawdy istoty: „interpretuje więc siebie - pomimo aktywności swych poszukiwań, pomimo swojej spontaniczności - jako obejście, którego używa istota, by się uporządkować i w ten sposób by pojawić się naprawdę, by pojawić się w prawdzie [...] Wszystko jest więc po tej samej stronie, po stronie bycia. Ta możliwość pochłonięcia podmiotu, któremu istota się powierza jest właściwością istoty". W ten sposób „bycie - pomimo, a może w skutek swej skończoności - ma istotę otaczającą, pochłaniającą, zamurowującą" (AE 171). Krótko mówiąc bycie jako istota to totalność, która przeziera nie tylko z myśli Hegla, ale także $\mathrm{z}$ idei horyzontu u Husserla i z bycia Heideggera.

Lévinas interpretuje tak rozumiane bycie jako nieudaną próbę wyjścia hipostazy z jej samotności, a więc wyraz jej egoizmu, chęci sprowadzenia wszystkiego do siebie samej, otulenia w swą własną tożsamość. Gdyż inteligibilność jest zawsze immanencją i zarazem wyrazem egoistycznego conatus essendi. W ten sposób dokonuje się nie tylko filozofia, lecz praktyka gwałtu: gwałtem jest już sama wola oświetlania i pojmowania rzeczy: „oświetlać, to odejmować bytowi jego opór" (TI 14). Ale gwałt ten prowadzi do dalszych: do wszelkich form życia, które zmuszają ludzi do podporządkowania się całości i ostatecznie do totalitarnego z istoty państwa. Gdyby bycie było jedyną postacią relacji międzyludzkich to, jak mówił Heraklit, wojna byłaby matką wszystkiego, gdyż ontologia jest już tyranią i prowadzi nieuchronnie do totalizmu. W ten sposób indywiduum, ludzki psychizm, który jest sobą jedynie wobec drugiego, zostaje umieszczony obok drugiego jako element całości, która jest anonimowa. Ta to anonimowość esencjalności powraca do nas w postaci bezosobowości fenomenu il y $a$, w nieznośnym „brzęczeniu” niezniszczalnego bycia (AE 208). Powróciliśmy po spirali do punktu wyjścia.

Co jednak ten fenomen nam teraz mówi? To, że esencja, która potwierdza naszą wolność myślących, samoistnych substancji, naprawdę wyzuwa nas z samych siebie, alienuje, ukazując, że konstytuuje nas najgłębiej to, co inne, ob ce: absurdalne bycie. Ale czy tylko ono?

Bezsens, w jaki zmienia się anonimowość bycia znaczy dla Lévinasa innym, pozaontologicznym znaczeniem. Jest to przemiana aktywnej intencjonalności w „pasywność, w której cierpienie przez to, co inne alienacji przechyla się w cierpienie dla innego relacji jeden-dla-drugiego w głębi pasywności" 2 . A „inne - przyjęte na siebie - jest Drugim” (TA 175). Bezsens wskazuje w ten sposób na źródło wszelkiego sensu: jeden-przez-drugiego jest możliwy

${ }^{2}$ H. Valavanidis-Wybrands, Veille et il y $a$, „Exercises de la Patience” $1: 1980$ s. 61. 
jedynie dzięki jeden-dla-drugiego nakazu bezgranicznej odpowiedzialności i ofiary. Tak więc ,intryga etyczna” wyprowadza nas dopiero poza samych siebie, gdyż stawia nas w obliczu Innego jako takiego, który rozbija moją tożsamość. Ale tym samym wyprowadza nas poza ontologię, wszelki dyskurs i prawdę. Możemy ją jednak tropić poprzez język, który — jak w zapytywaniu — kieruje się wszak ku drugiemu, poprzez czasowość, której diachronia wskazuje na nieusuwalną róż ni c ę między mną a drugim, poprzez śmierć jako wkroczenie w niepoznawalność. Wszędzie Inny rozbija bycie jako istotę i mnie jako wciąż odzyskujący siebie, egoistyczny i ateistyczny podmiot, każąc mi być zakładnikiem za drugiego. I dopiero odnalazłszy to, co „ponad byciem” mogę próbować odzyskiwać s e $\mathrm{n}$ s bycia i prawdy.

Podsumujmy. Bycie dla Lévinasa to anonimowość absurdalnego istnienia, która okazuje się pochodną tożsamości is t o ty, jako elementu nigdy nieosiągalnej, ale zawsze projektowanej wiedzy absolutnej, w której to, co niepowtarzalne staje się tylko egzemplarzem gatunku, a relacje międzyludzkie mają charakter ,jeden-obok-drugiego”, a nie ,jeden-wobec-drugiego” i „dla-drugiego". To także imperializm troszczącego się o siebie, tożsamego podmiotu, dla którego to, co inne jest przeszkodą i dlatego musi być wchłaniane przez totalitarne struktury. To jednak także jeden ze znaków Innego, obcego, który wdarłszy się w tożsamość zarazem przekreśla i ratuje kruchy sens bycia.

2. Gabriel Marcel rozpoczyna swoją koncepcję bycia w miejscu, w którym Lévinas ją poniekąd kończy: w krytyce wiedzy absolutnej. Wiedza absolutna nie tylko wchłania w swe bezosobowe sieci wszystko, co indywidualne i nie tylko jest nieosiągalna. Jest ona ponadto sprzeczna sama ze sobą, gdyż jakkolwiek chciałaby wessać w siebie myśląc podmiot, zawsze jest do niego w koncu zrelatywizowana. Może być ona jedynie utopią lub ideą regulatywną, ale nigdy nie może stać się realnie absolutna, musiałaby bowiem albo objąć w sobie albo $\mathrm{z}$ kolei wyeliminować realne, skończone podmioty wraz z ich niepowtarzalnością i ich błędami; ale w obu wypadkach unicestwiłaby samą siebie zarówno jako prawdę jak jako absolut.

Ale właśnie dlatego wiedza absolutna nie jest byciem, nie może nim być bowiem fikcja. Bycie to to, w czym podmiot myślący, ale także wcielony uczestniczy, partycypuje zarówno poniżej, jak powyżej poziomu struktur pojęciowych, z czego czerpie wszystkie swe myśli i pragnienia i ku któremu zarazem się zwraca. Nie będąc bynajmniej wiedzą absolutną, bycie jest ta je mnicą, to znaczy czymś, co nie daje się zamienić w problem, który dotyczy zawsze przedmiotów, tj. tego, co tożsame ze sobą i możliwe do scharakteryzowania. Tajemnica nie jest, jak śmierć u Lévinasa, tym co niepoznawalne, a „co stanowi jedynie granicę problematyczności, która nie może zostać zaktualizowana bez sprzeczności. Rozpoznanie tajemnicy, przeciwnie, jest aktem umysłu w sposób istotny pozytywnym [...] w stosunku do którego być może wszelka pozytywność określa się w sposób ścisły" (EA 170). Kiedy np. pytam, kim jestem, to 
mogę mieć tak długo złudzenie, że jest to problem, z którym mogę się uporać, póki nie rozumiem, że moje ,jestem” jest już zawsze nie przeze mnie założone: proces problematyzacji „pozostaje wewnątrz pewnej afirmacji, którą raczej jestem, niż ją wypowiadam" (PA 166). W tym sensie bycie nie jest mi nigdy dane.

Bycie to zatem najpierw to, w oparciu o co wszelką myśl i doświadczenie jest dopiero możliwe: fundament, czy raczej „sytuacja-trampolina”; dlatego paralogizmem jest pytanie: „co to znaczy być”? „ponieważ możemy pytać jedynie wychodząc z bycia" (PST 82). Ale bycie to także to czego całymi sobą się domagamy, co jest korelatem „wymogu ontologicznego”. Jesteśmy bowiem nie tylko zanurzeni w faktyczności, której nie tworzymy, ale jesteśmy także żywym wymogiem pełni, absolutu, ku któremu z kolei wszelka przedmiotowość i problematyczność ma być przek roczon a. Między tymi dwoma ekstremami: „hypo-” i „hyperproblematycznym” mieści się Marcelowska filozofia partycypacji podmiotu w byciu, która nasyca rozumienie bycia konkretnymi treściami.

Czym w tym świetle jest istnienie? I s t n i e nie to jeszcze nie bycie, jakkolwiek to brzmi paradoksalnie: gdyż istnienie nie jest wystarczającą odpowiedzią na wymóg ontologiczny. Ale dookreśla ono partycypację w tajemnicy przez to, że wprowadza w nią kluczowy moment in t y m ności, gdyż istnienie jawi się wraz z moją cielesnością przez którą odczuwam więź zarówno z samym sobą, jak ze światem, tak pierwotną, że „afirmacja «ja istnieję» dąży do zlania się $\mathrm{z}$ afirmacją «istnieje świat»", przy czym zarówno ja, jak świat muszą być rozumiane jako „negacja wszelkiej poszczególnej treści” (JM 313). Źródłem światla nie jest więc Husserlowska Ur-Impression monady lecz Ur-Gefühl intymnej, a więc nie obcej i bezosobowej więzi jako podstawowego tworzywa rzeczywistości oraz - wbrew Heideggerowskiej różnicy ontologicznej — „nierozdzielności istnienia i tego, co istnieje" (JM 313). Cielesność jest w ten sposób źródłem wszelkiej komunikacji jako takiej, której nie można a priori wyznaczyć żadnych granic; dlatego wcielenie Boga nie jest w myśli Marcela absurdem. Ale cielesność niesie w sobie także mroczność, możliwość wychylenia w stronę zamykającego mnie posiadania, które oddziela mnie od drugich, a także cierpienie i śmiertelność. $\mathbf{Z}$ tego punktu widzenia cielesność jest generatorem zdrady i rozpaczy, a w końcu nihilizmu, przeciwko któremu budzi się w nas właśnie „wymóg ontologiczny”. Oto dlaczego istnienie nie jest byciem.

Lecz doświadczenie intymności istnienia rozświetla sens wyjściowej „sytuacji-trampoliny” i prowadzi do rozumienia bycia jako „węzła intersubiektywnego". Gdyż jestem jako podmiot tylko dlatego, że poprzedzają mnie i niosą związki z innymi: „w rzeczywistości w oparciu o drugiego i drugich i tylko w oparciu o nich możemy zrozumieć siebie" (ME 11n.). Węzeł intersubiektywny jest „jakby korzeniem wszelkiej wypowiedzi [...] tajemniczym korzeniem języka", ludzkim środowiskiem, w którym się poruszam, powietrzem, którym 
oddycham. Dlatego także „węzeł intersubiektywny nie może mi być dany, ponieważ jestem w niego poniekąd wplątany" (ME 14).

Ale choć węzeł intersubiektywny „nie może być w żadnym sensie stwierdzony”, to jednak „może zostać rozpoznany” (ME 14), to znaczy uznany w sposób wolny i wówczas otwiera się na bycie jako wspól-bycie, co-esse, w którym decyduje się już to czy naprawdę jesteśmy czy nie. Gdyż zawsze mogę albo zamknąć się w mym egoistycznym posiadaniu i „myśleniu” jedynie na temat innych, albo „myśleć o” innych i być z nimi nawet ponad śmiercią, i w ten zarazem sposób naprawdę być samemu. Nie ma co-esse bez jakiegoś dialogu między ja i ty - ale nie on jest naprawdę ważny, lecz co innego: obecność. Obecność to z jednej strony „tajemnicza potęga afirmacji” (JM 310) kogoś, kogo kocham, choć go nie widzę, a nawet kwiatu, który oglądam w skupieniu; $\mathrm{z}$ drugiej strony moja obecność dla kogoś nie jest równoznaczna ani z obecnością fizyczną, ani nawet z uwagą, lecz z „rozporządzalnością”, ofiarowaniem całego siebie dla biedy drugiego. Nie jest to formalne ,jeden-dla-drugiego", lecz wypełnienie go konkretną „obecnością” i właśnie dlatego bycie z drugim: bliskość nie do pomyślenia bez wolności, zgody i konkretnego gestu prowadzącego do ontologicznej właśnie, a nie tylko etycznej sytuacji.

Tylko, że co-esse z drugim człowiekiem w warunkach skończonej egzystencji nie wyczerpuje potencjalności zawartych w wymogu ontologicznym, który jest wymogiem pełni, pełni przeżywanej, całkowicie różnej od doskonałości jakiegoś ens realissimum. Jest to najpierw wymóg pełni sensu: „Trzeba, aby było [...] bycie, aby wszystko nie redukowało się do gry pozorów, następujących po sobie i niespójnych [...] lub do historii opowiedzianej przez idiotę, by podjąć wyrażenie Szekspira" (PA 261). Ten wymóg sensu nie tylko dla intelektu, lecz dla całego człowieka jest wymogiem transcendowania od zawsze skończonych pół-prawd egzystencjalnych ku „światłu” pełnej prawdy jakby przeznaczonych nam więzi z innymi podmiotami. Dlatego wymóg ontologiczny to, po drugie, wymóg absolutnej, ale nieodłącznej od prawdy miłości ponad wszelkimi możliwymi zdradami i ponad śmiercią. W każdej autentycznej miłości zawarty jest bowiem wymóg absolutnego porozumienia oraz nieśmiertelności: człowiek naprawdę kochający mówi: „ty nie umrzesz” i profetyczna pewność tej nieśmiertelności jest samym rdzeniem nadziei (ME 155).

Ale zarazem właśnie dlatego bycie jako pełnia jest korelatem p ró by, bez związku z którą jest nie do pomyślenia. W próbie po pierwsze jest uwikłane pytanie: „stanę czy nie na wysokości siebie samego”, w którym ujawnia się dystans między moim życiem po prostu, a moim byciem: „nie jestem moim życiem" (PA 274). Moje bycie, którego wartość jest utkana z miłości innych do mnie, jest w próbie stawką, która może być zgubiona lub ocalona. Po drugie ocalenie tej stawki jest proporcjonalne do tego, jakie są moje miłości i co z nimi czynię: najpierw więc próba jest filtrem ujawniającym co w życiu „mu się opiera, a co nie, co się ulatnia, a co zostaje na dnie tygla” (JM 178), jest więc 
próbą samych wartości, których opór wobec czasu odsłania ich wysokość; po wtóre próba jest zawsze próbą mojej wierności. Próba jest więc „samym polem wolności" (JM 229), które zarazem ujawnia, co naprawdę jest we mnie i ponad mną, gdyż „bycie jest tym, co opiera się [...] wyczerpującej analizie dotyczącej danych doświadczenia, które dążyłoby do stopniowego redukowania ich do elementów coraz bardziej pozbawionych wewnętrznej czy znaczącej wartości” (PA 262). Skoro tak, to bycie jest w swym rdzeniu „tym, co niezniszczalne" (ME 60), tym, co trwa poprzez wszystkie próby i co dlatego przenosi nas ponad czas, w wieczność i w ten sposób z kolei może być fundamentem naszych wierności.

Jest to jednak możliwe tylko dlatego, że tak rozumiane bycie, w którym możemy coraz bardziej uczestniczyć, odsłania się nam samo jako pełnia wierności: „Bycie jest tym, co nie zawodzi; bycie jest wówczas, gdy nasze oczekiwanie jest wypełnione; mówię o tym wyczekiwaniu, w którym uczestniczymy całymi sobą" (JM 177). I tylko wówczas, gdy czujemy się przez owo bycie — nieodłączne od Bytu — „uchwyceni” (EA 63), rozumiemy także, że nasze wspól-bycie, a więc i bycie w ogóle jest darem, który domaga się od nas odpowiedzi jako odpowiedzialności: „coś nam zostało powierzone” (EA 16). Dlatego ostatecznie w swym najgłębszym rdzeniu bycie jest niczym innym jak „miejscem wierności” (EA 55). Miejsce to jest równocześnie - ponad śmiercią - miejscem nadziei: oto dlaczego można i trzeba utożsamić problem bycia i problem zbawienia (JM 180).

Zrekapitulujmy. Bycie dla Marcela nie oznacza ani horroru anonimowości, ani identyfikacji związanej z egocentryzmem, lecz raczej jest nazwą na pewną dynamikę, napięcie: na sytuację wyjściową i horyzont dojścia ludzkiej drogi, która jest drogą ukierunkowaną, a nie drogą donikąd ${ }^{3}$. Jej sensem jest coraz lepsze rozpoznawanie tajemnicy, w którą jesteśmy od początku zanurzeni jako uniwersum miłości i jako daru, dzięki któremu już jakoś jesteśmy, a zarazem mamy być naprawdę. Pod warunkiem, że rezygnujemy z postawy „mieć” na rzecz postawy „być” dla drugich, że nie poddajemy się rozpaczy wobec zła i śmierci, lecz mamy nadzieję na pełnię prawdy i miłości. Jest to możliwe, o ile słyszymy i odpowiadamy na apel ze strony „ontologicznej trwałości”, domagającej się od nas wierności, miłości i nadziei do końca.

\section{II}

1. Powróćmy do Lévinasa i zobaczmy, jak w świetle jego koncepcji bycia rysuje się jego filozofia Boga, której program zarysował tak: „zrozumienie Boga nie zarażonego przez bycie jest możliwością ludzką nie mniej ważną i nie

\footnotetext{
${ }^{3}$ Por. wypowiedź G. Bergera w dyskusji zamieszczonej PST 114.
} 
mniej kruchą co wyprowadzenie bycia z zapomnienia, w jakie wpadło w metafizyce i ontologii" (AE X).

Najistotniejszą właściwością bycia jest - jak pamiętamy - jego anonimowość, a także immanencja: bycie jako takie wyklucza w sposób istotny transcendencję. Tymczasem człowiek może nie ulec totalizmowi i zachować swoją niepowtarzalność tylko pod warunkiem spotkania z transcendencją Boga i drugiego człowieka. Ale jak jest możliwa w ogóle transcendencja? Jedynie poprzez cz a s jako taki, to jest jego diachronię, o ile wymyka się ona synchronii tożsamości. Możliwość ta rysuje się już w samej pierwotnej świadomości czasu oraz w tajemnicy śmierci. W jaki sposób? Identyfikacja polega na podejmowaniu w teraźniejszości tego co właśnie przeszłe, na retencji. Ale między teraźniejszością a tym, co właśnie minęło jest „przeciąg czasu”, odstęp, który jako taki wymyka się świadomości zanim go nie podejmie w retencji. W ten sposób po pierwsze świadomość jawi się jako nieuleczalnie pasywna: coś jej się wymyka, czego może się, by tak rzec, jedynie domyślać; po drugie czas jawi się jako nieciągły: — ,jeden-poza-drugim” — nie tyle czas Husserla, co Kartezjusza; czas, który staje się w ten sposób figurą Innego ${ }^{4}$.

Także śmierć wyłania się z wymiaru przyszłości, pierwotniejszego niż identyfikacja i niemożliwego do synchronizacji: „śmierć nie jest nigdy teraz. Kiedy śmierć przychodzi już mnie nie ma, bynajmniej nie dlatego, że jestem nicością, lecz że nie jestem w stanie jej ująć" (TA 166 n.). Tak więc śmierć jako taka mi się wymyka, nie jest żadną moją możliwością (jak u Heideggera), lecz właśnie skrajną niemożliwością. W obu przypadkach: z „niepamiętnej” przeszłości i z obcej wszelkiemu światłu przyszłości wyłania się - Transcendencja (TA 166). W ten sposób podmiot ludzki ma do czynienia z czymś, co go przekracza i czego $\mathrm{z}$ tej racji nie może w świadomości pomieścić. Dlatego podstawową figurą tej absolutnej transcendencji jest dla Lévinasa kartezjańska idea Nieskończoności. Gdyż idea Nieskończoności jest jedyną ideą, której zawartość przekracza nieskończenie skończony intelekt, kwestionując jego prawo do konstytuowania i obejmowania w jedną całość wszystkiego. Nieskończoność poprzez swą ideę wkracza w nas i rozbija od wewnętrz naszą wygodnicką tożsamość. Ale zarazem budzi w nas w ten sposób pragnienie absolutnej transcendencji, tego, co niewidzialne i niemożliwe do zawładnięcia, całkowicie inne, ,ponad byciem”. To pragnienie $\mathrm{z}$ istoty niemożliwe do zaspokojenia nazywa Lévinas pragnieniem Dobra. Dobro, które według Platona jest „ponad bytem” — to inna nazwa na Nieskończoność (TI 19-23; EDE 171-175)5. Dobro i Nieskończoność - to podstawowe kategorie transcendencji pozaontologicznej, a więc i ponadlogicznej, lecz nie ponadosobowej, gdyż wskazują na kluczowy tu wymiar „wysokości” i nietykalności, świętości.

${ }^{4}$ A. F a essle r, L'intrigue de tout-autre, [w:] E. Lévinas. Cahiers de la nuit de la nuit surveillée, Paris 1984, s. 124.

${ }^{5}$ E. Lévin as, De Dieu qui vient à l'idée, Paris 1982, s. 104 n. 
Ale dobro nie byłoby absolutną transcendencją, gdyby stawało się w jakimkolwiek sensie korelatem naszego pragnienia. Właściwością Nieskończoności jako Dobra u Lévinasa jest to, że „odpycha” jakby od siebie nadając pragnieniu charakter wyłącznie etyczny, to znaczy skierowując je ku drugiemu człowiekowi jako nakaz dawania siebie. Pragnienie Dobra przemienia się konkretnie w obsesję odpowiedzialności wobec drugiego: obcego, sieroty, wdowy, których bynajmniej nie pragnę, ale do których stosunek może być dlatego w pełni bez-inter-esowny, jak pisze Levinas chcąc podkreślić, że nie ma on nic wspólnego z byciem, esse, że jest właśnie „poza byciem”. Drugi ściąga mnie, by tak rzec, poprzez swoją nagą, ale zarazem niepoznawalną twarz, zawsze jedyną, wyrwaną z homogenizującego kontekstu świata, w tym sensie abstrakcyjną i transcendentną. W nagości tej twarzy odczytuję przykazanie „ty nie zabijesz" i właśnie ono jest jedynym, enigmatycznym, lecz przemożnym śladem już nie tylko Nieskończoności, lecz samego Boga. Wyłania się ono z niepamiętnej przeszłości absolutnej transcendencji i odsłania moją najgłębszą pasywność, pasywność stworzenia (TI 268 nn.). Odpowiedzialność za drugiego jest bowiem wcześniejsza niż moja wolność i drugi jest we mnie bliżej, bardziej wewnątrz niż ja sam, rozbijając moją ontologiczną identyfikację, ale stając się za to przekaźnikiem absolutnego, tajemniczego, czy lepiej enigmatycznego wybrania i przez to dopiero istotnej, etycznej, a nie ontologicznej jedyności, indywiduacji. I właśnie w tym wybraniu, które odczytuję z twarzy drugiego daje o sobie w szczególny sposób znać transcendencja Boga jako tajemniczego „trzeciego".

Bóg bowiem — Nieskończoność, Dobro — nie może się stać nigdy Drugim, to znaczy „Ty” dialogu, tak, jak nie może się stać tematem dyskursu. Jest jedynie w twarzy drugiego śladem nieodwracalnej nieobecności Tego, który „przeszedl”, który się wycofał, absolutnie transcendentny, w „przeszłość Innego, gdzie zarysowuje się wieczność - absolutna przeszłość, która jednoczy wszelki czas” (EDE 201). Przeszłość, która jednak nie przestaje być wpisanym w moją tożsamość nakazem. W ten sposób Bóg jest jedynym imieniem całkowicie ponad byciem: „Imię poza istotą czy ponad istotą, jednostka wcześniejsza niż ujednostkowienie nazywa się Bogiem. Poprzedza wszelką boskość, to znaczy boską istotę, której domagają się jak jednostki skrywające się w swym pojęciu - fałszywi bogowie" (AE 68).

2. U Marcela Bóg także nie jest istotą i także jest niemożliwy do tematyzacji. Ale nie dlatego, że jest ponad byciem, lecz wprost przeciwnie: właśnie dlatego, że jest, by tak rzec, byciem w jego maksimum. Bóg bowiem jest przeciwieństwem przedmiotu jako takiego, który odznacza się tym, że będąc możliwy do charakteryzacji jest zarazem „wyspowy”, to znaczy, że więź między nami a nim jest przerwana: „nie uznajemy, że skierowuje się do nas, lub, że my

\footnotetext{
${ }^{6}$ A. Faessler, jw., s. 125 n.
} 
jesteśmy dla niego” (JM 144). Przedmiot jest zawsze właśnie „trzecim”, obcym w dialogu, który prowadzę z „tobą” na ,jego” temat - jest elementem „,relacji triadycznej". Natomiast Bóg jest — jeszcze bardziej niż w każdej innej relacji diadycznej ,ja-ty" - samą bliskością, to znaczy, że ani On dla mnie, ani ja dla Niego nie mogę być obojętny, a zatem nie może On być „trzecim”: „myśleć Boga jako rzeczywistego, to afirmować, że jest ważne dla Niego, iż w Niego wierzę, podczas gdy myśleć stół, to go myśleć jako coś całkowicie obojętnego wobec faktu, że go myślę. Bóg, którego nie interesowałaby moja wiara nie byłby Bogiem, lecz zwykłym jestestwem metafizycznym" (JM 153). Inaczej mówiąc „Bóg jest Ty Absolutnym, które nie może nigdy stać się Nim” (JM 137).

Wynikają z tego najpierw dwie konsekwencje. Po pierwsze dowody na istnienie Boga są z góry pozbawione sensu m.in. dlatego, że Bóg nie może być przedmiotem dowodzenia: „to, czego istnienie mogłoby być dowiedzione nie byłoby, nie mogłoby być Bogiem" (JM 223). Po drugie wszelka mowa na temat Boga jest z góry podejrzana: „gdy mówimy o Bogu, wiedzmy, że nie o Bogu mówimy" (JM 158). Natomiast - w przeciwieństwie do Lévinasa - Bóg jest par excellence Ty modlitwy, inwokacji, gdyż jedynym sposobem, by w ogóle do Boga się odnosić, czyli „myśleć o Nim”, to się modlić: „modlić się, to aktywnie odmawiać myślenia Boga jako porządku, to myśleć Go naprawdę jako Boga jako czyste Ty" (JM 159).

Ale modlitwa może być mniej lub więcej czysta i jest tym bardziej czysta, im bardziej „duch modlitwy” jest „pewnym sposobem, bardzo pokornym i żarliwym zjednoczenia się z [...]" Bogiem (ME 103), to znaczy bycia-z-Nim, coesse: „zapytywać siebie, w jaki sposób mogę myśleć o Bogu, to poszukiwać, w jakim sensie mogę być z nim” (EA 42). Jednakże „w istocie pojmujemy zjednoczenie tylko w stosunku do podobnych nam; integrujemy się wówczas w całość, której elementy są homogeniczne. Lecz tutaj nic takiego nie jest do pomyślenia. Stąd tajemnica polega na fakcie, że mam się wpisać w to, co nieskończenie mnie przekracza" (ME 103). Jak to jest możliwe? Na to pytanie można dać dwie odpowiedzi. Jedna $\mathrm{z}$ nich wynika z odczytania pierwotnego sensu teorii partycypacji. Dotarliśmy do niej stwierdzając konieczność przekroczenia wiedzy absulutnej, dla której skończony podmiot jako taki jest bez znaczenia; tymczasem wszelka wiedza i prawda są dla skończonego podmiotu, przekracza on ją więc, jest względem niej wolny. Ale wolność ta byłaby z kolei pusta, gdyby nie mogła akceptować własnej konkretnej i wcielonej skończoności. Może to jednak uczynić tylko uwierzywszy, że jest ona sensowna - choć niezrozumiała z punktu widzenia myśli pojęciowej; to zaś oznacza, że jest ona chciana i stworzona przez Boga. Przekraczam więc epistemologicznie wiedzę absolutną o ile równocześnie przekraczam ontologicznie moją skończoną wolność ku Bogu, absolutnemu Ty, który mnie nagruntowuje: „duch zakłada Boga jako Tego, który jego zakłada" (JM 46). Dlatego bycie, w którym uczestniczę ma od razu charakter personalny, tego co nie zawodzi i co jest miejscem wierności, 
a partycypacja jest naprawdę transcendowaniem, a nie rozpływaniem się w anonimowości.

Taka wiara w Boga „nie tylko dotyczy bycia - być może, że te słowa nie mają nawet żadnego dokładnego sensu - lecz jest z bycia, jest moim byciem, jest naprawdę sednem tego, czym jestem" (RI 223). Gdyż w głębi nas samych „nie jesteśmy dla samych siebie” (EA 125), co Lévinas pisząc o Marcelu tak słusznie komentuje: „Byt boski, którym nie jesteśmy, Ty absolutne, którego spotykamy jako transcendentnego, jest także byciem, które nas niesie i nas kocha"7. Znaczy to, że Bóg jest zarówno transcendentny jak immanentny, co Lévinas Marcelowi właśnie zarzuca; ale — czy idea Nieskończoności nie mówi na swój sposób tego samego? Zadanie filozofa polega odtąd na tropieniu „oślepionej intuicji" wiary w aktach transcendowania dokonujących się w ludzkich próbach życiowych i wyrywających wołanie do Ciebie jako „absolutnej ucieczki”, abyś był ze mną w próbie (JM 220), abyś był dla mnie „absolutną obecnością” (JM 321). Apel, który ,jest możliwy tylko dlatego, że w głębi mnie jest coś innego niż ja, coś bardziej wewnątrz mnie niż ja sam" (EA 181), co rości sobie do mnie prawo; lecz „właśnie dlatego, że nie jest On kimś innym, lecz Kimś bardziej wewnątrz mnie niż ja sam, rości sobie do mnie prawo. To prawo daje się pojąć jako funkcja miłości, a nie władzy" (RI 134). W ten sposób mój apel okazuje się już odpowiedzią. Odpowiedzią, która zawsze zresztą może nie zostać udzielona: gdyż dramat naszej wolności polega na tym „czy afirmuje Byt i otwiera się na niego - czy Go neguje i tym samym się zamyka" (EA 175).

Dlatego druga odpowiedź na możliwość partycypacji w Bogu mówi o duchu ofiary. „Należąc do Boga mam Mu dać siebie, zwrócić się w jego stronę” mimo że choć „daję Bogu, to, co daję już do Niego należy” - na tym właśnie polega bycie stworzonym (JM 158 n.). Zresztą czyż prawdziwy „duch modlitwy nie przedstawia się przede wszystkim jako gotowość przyjęcia tego, co może mnie wyrwać ze mnie samego?" (ME 105). Otóż tym, co wyrywa mnie najskuteczniej ze siebie jest spotkanie drugiego człowieka i miłość, która dokonuje „wstępnego rozbicia mnie samego" (JM 228). Miłość ma nieoddzielne od siebie dwie strony: „kocham tym autentyczniej, im kocham mniej dla siebie”, a zarazem miłość jest wymogiem „wspólnoty coraz bardziej niepodzielnej, w łonie której ja i drugi dążymy do stopienia się coraz doskonalszego" (ME 98). Dlatego jeśli jesteś dla mnie „ty”, a nie „nim”, to modląc się o coś dla siebie „w rzeczywistości proszę Boga za nas” (JM 219), a Bóg jest „samym cementem" spajającym naszą miłość ${ }^{8}$.

${ }^{7}$ E. Lévin as, Martin Buber et Gabriel Marcel, „Revue Internationale de Philosophie” 126 : 1978 s. 499 n.

${ }^{8}$ G. Marce l, Homo viator, Paris 1944, s. 77. 
Gdzie tkwi rdzeń różnicy między obu filozofiami: Lévinasa i Marcela? Niewątpliwie w koncepcji transcendencji, w szczególności transcendencji Boga w relacji do idei bycia. Spróbujmy najkrócej pokazać na czym polega ta różnica.

1. Transcendencja u Lévinasa musi być poza czy ponad byciem, ponieważ bycie jest par excellence immanencją, rozumianą jako zamknięcie w tożsamości. Lévinas myśli bowiem bycie w ślad za idealizmem niemieckim dwojako: zasadniczo w perspektywie pojęcia, a więc czegoś najbardziej ogólnego, homogenicznego, zrównującego ze sobą wszystkie byty w zamkniętą całość, totalność oraz w perspektywie konstytucji transcendentalnej, a więc czegoś, co wychodzi z podmiotu i do niego wraca. Nie jest więc dla niego bycie ani - jak w myśli średniowiecznej — tym, co właśnie najgłębiej indywidualizuje, gdyż decyduje o tym, że byt jest sobą, niezamienialnym z jakimkolwiek innym a równocześnie tym, co tworzy hierarchię esencji, powiązaną nićmi analogii; anijak w myśli Marcela - samym sensem więzi między bytami, lecz sensem nie konstatowanym, a wymaganym i zarazem upragnionym. Dla Lévinasa bycie jest tylko homogeniczną, jednoznaczną całością zadającą gwałt niepowtarzalności.

Wskutek tej perspektywy również poznawanie nie jest dla Lévinasa nawiązywaniem poprzez prawdę swoistych więzi z tym, co napotykane jako niezależne i różne i co nie daje się nigdy do końca przez podmiot oswoić. Poznawanie dla Lévinasa to zasadniczo wyłącznie pożeranie przedmiotów przez łapczywy podmiot i włączanie-w swoją posesywną orbitę. Co prawda domaga się tego poznawania, tematyzacji itd. obecność „trzecich” i konieczność sprawiedliwości między podmiotami, która jest u korzenia porównywania i ogólności; ale poznawanie to i dyskurs musi być stale „,brany w nawias” i podgryzany sceptycyzmem, by nie wyrodzić się w idolatrię. Dlatego jednak sama idea prawdy, tak blisko $\mathrm{z}$ ideą bycia spokrewniona staje się ideą $\mathrm{w}$ istocie podejrzaną.

Podmiot poznania bowiem jest wolnością na wskroś egoistyczną. Dlatego nieusprawiedliwiony jest dla Lévinasa nie tylko conatus essendi, ale nawet idea zbawienia w stopniu, w jakim koronująca je - ex hypothesi-szczęśliwość miłosnego zanurzenia w Bogu groziłaby zrzucaniem ze siebie wybrania na cierpiącego zakładnika za wszystkich. I dlatego może woli Lévinas statyczną w istocie analizę warunków możliwości wolności niż samych możliwości stojących przed wolnością i użytku, jaki z nich ona robi.

Z tych wszystkich powodów to, co jedynie ważne: święty Bóg, który przebija niejasną, lecz wzniosłą i wymagającą enigmą poprzez twarz drugiego musi „być” wraz z tą twarzą ponad byciem, myślą, pragnieniem, szczęściem, a nawet wzajemną miłością. Bóg - to przenikająca poniżej świadomości, wolności i tożsamości bytu nieskończoność bolesnego ciężaru obowiązku względem niewybranego drugiego. 
Wolno jednak może zapytać: czy Bóg ten w jakimkolwiek sensie jest i co to by miało znaczyć? I co, jeśli nie jakaś postać poznania - choć nie dzięki nam samym - upoważnia nas do tego by o Nim mówić? A wreszcie: czy Jego bliskość w mojej rozbitej tożsamości nie jest także jego immanencją, a nie tylko transcendencją i czy przeciwstawienie to jest istotnie w wypadku Boga tak radykalne, jak sądzi Lévinas?

2. Dla Marcela bycie przenika każdy poszczególny byt dlatego, że ów byt stanowi jakiś niepowtarzalny instrument w symfonii miłości (ME 188), której jeszcze w pełni nie ma i może nie być, nie dlatego, że bycie jest skończone, tylko dlatego, że dokonuje się w przestrzeni między boską wiernością, a ludzką wolnością, która może do końca wybierać zło, a nie dobro, zdradę a nie wierność. Bycie jest nie dlatego odniesione do podmiotu, że stanowi jedno z samoalienującym snuciem wiedzy absolutnej, lecz ponieważ jest stawką w dramacie zbawienia lub potępienia. Bycie jest więc w sensie ścisłym korelatem mojej wolności, która jednak polega nie na tworzeniu ex nihilo pewnej rzeczywistości, lecz na pokornym wzrastaniu w prawdzie uczestnictwa w tym, co mnie przerasta i właśnie nie jest na moją miarę - w byciu.

Skoro chodzi w byciu o wzrastanie w prawdzie, to prawda nie jest przede wszystkim prawdą wiedzy, lecz prawdą egzystencji. Lecz zarazem poznawanie nie jest $\mathrm{z}$ istoty przyrostem posiadania, może być bowiem także - choć nie musi - pokornym zanurzaniem się w niewyczerpane bogactwo w szczególności innych podmiotów i w głębię tajemnicy — respektującej odrębność - miłości. Dla Marcela miłość jest alfą i omegą rzeczywistości — oto dlaczego wolno kochać także siebie oczyma innych i wolno pragnąć nie tylko mojej obecności dla drugich, ale także drugich dla mnie i ostatecznie szczęścia współ-bycia z Bogiem w pośrodku królestwa miłosnego co-esse.

W tej sytuacji Bóg nie może być ponad byciem — musi właśnie móc być ale też samo bycie musi tu być rozumiane w perspektywie „serca”, którym Bóg wypromieniowuje miłość wiążąc się z ludźmi i ludzi między sobą i wiernie tę miłość podtrzymuje, pozwalając przebrnąć przez próby i ryzyko grożącej rozpaczy. Tylko w perspektywie idei wierności Boga, który z nami jest nawet wówczas, gdy my nie jesteśmy z Nim, choć zarazem do niczego nas nie przymusza — tylko w tej perspektywie pojęcie partycypacji w byciu uzyskuje u Marcela swój pełny sens. Jest to sens niemożliwego prawie do pomyślenia, dokonującego się wciąż tajemniczo zwycięstwa rze czy wis t oś ci dobra nad rzeczywistością zła i nad kruchością do końca zależnej także od siebie wolności.

Czy nie da się zatem obronić związku bycia i Boga tak, jak to proponuje Marcel? Sądzę, że można i sądzę nawet, że nie jest to jedyna możliwa tego związku obrona. Wolno jednak z kolei zapytać, czy Bóg Marcela może być także milczącym świadkiem „Szoachu”, łamiącego podstawowe moralne nakazy? I czy prorocka myśl Lévinasa nie jest niezastąpiona? Nigdy bowiem nie dosyć przypominać, że droga do zbawienia, czyli prawdziwego co-esse wiedzie przez 
wyzucie dla drugich i kenozę, taką, jakiej przykład mamy w śmierci i życiu Jezusa. W tej perspektywie umieranie sobie w różnych postaciach i śmierć sama nie jest po prostu wkraczaniem nicości w nieprzenikalny byt parmenidiański, nie jest, jak mówi Lévinas, nicością, lecz właśnie najgłębszą t a j e m ni cą (TA 129); to znaczy niepokojącym przekraczaniem — w którym nasze ,ja” zarazem się gubi i cudownie odnajduje - widzialnej skończoności ku niewidzialnej nieskończoności, w której bycie uzyskuje może właśnie swój najgłębszy sens i spełnienie.

\section{L'ÊTRE ET LA TRANSCENDENCE - LÉVINAS ET MARCEL}

\section{Résumé}

L'article entreprend la comparaison entre la métaphysique de „l'au-delà de l'être” d'Emmanuel Lévinas et l'ontologie de la plérôme de Gabriel Marcel, en liason avec leurs idées respectives sur la transcendence de Dieu. Selon Lévinas l'être est entièrement anonyme, aussi bien du coté de l'existence que du coté de l'essence, en alienant l'étant individuel et en déboucheant finalement dans le non-sens de „l'il y a”. Mais ce non-sens fait pressentir déjà une intrigue de l'autre qui se noue à travers la diachronie du temps, le questionnement même sur l'être, à travers la mort etc. et qui nous met face à l'idée de l'Infini et du Bien, indissolublement liées au visage de l'autrui et du prochain. Dieu et l'autrui signifient donc au-delà de l'être. Mais ce Dieu estil? Et cette conception, si profonde qu'elle soit, n'est-elle possible que par une pauvreté extrême de l'idée de l'être due à l'héritage de Hegel et de Heidegger qui en effet totalisent l'être en le coupant de la chaleur de l'humain?

C'est ici que la philosophie de Gabriel Marcel montre son actualité. Car pour lui l'être est un mystère dans lequel l'homme participe, non toutefois automatiquement mais proportionnelment au mouvement de la liberté qui renonce à son attitude de l'avoir, pour s'ouvrir au co-esse, à „l'êtreavec”, guidé par une secrète ,exigence ontologique”. Cette exigence demandé à l'homme de se purifier et de résister à toutes les épreuves de la vie en les transcendant vers un plénitude de l'être, dans le coeur de laquelle rayonne Dieu. Ainsi Dieu ne peut être chez Marcel „au-delà de l'être”, car l'être signifie finalement le royaume de l'amour au-delà duquel on ne peut plus rien penser. Mais ce royaume - et c 'est ici qu'on revient à Lévinas — n'est accessible qu'à travers l'offrande de notre vie pour les autres et par la kénoze dont l'exemple insurpassable nous a donné JésusChrist. Seulement cette kénose se fait — par la fidélité et l'espérance — une porte vers l'être dans sa plénitude qui lui-même est porté par l'amour fidèle de Dieu pour nous tous. 